Check for updates

Edinburgh, UK

Cite this as: BMJ 2020;369:m2609 http://dx.doi.org/10.1136/bmj.m2609 Published: 29 June 2020

\section{Covid-19: Scotland “on track” to eliminate virus}

\section{Bryan Christie}

Deaths and new infections from covid-19 have fallen to such low levels in Scotland that the first minister Nicola Sturgeon says the country is close to eliminating the virus.

On 26 June no deaths were recorded-the first time this has happened on a weekday since early March. Sturgeon described the event as "really significant." There were 17 cases of new infections on the same day but only five on 25 June. This compares with a peak of 430 daily infections recorded on 31 March.

Scotland has been badly affected by covid-19 with total deaths so far numbering 4119. The highest proportion $(47 \%)$ occurred in care homes, followed by hospitals (46\%). A cautious approach has been taken to lifting lockdown restrictions which have remained in place around two weeks longer than in England. Sturgeon said that exceptional progress had been made over the past few months because most people have stuck to the rules.

Figures from the National Records of Scotland show that deaths have fallen from a peak of 660 in the week of 20-27 April to 49 in 20-27 June. There has been a steady decline every week for two months. ${ }^{1}$

Devi Sridhar, professor of global public health at the University of Edinburgh University, said that the rate of decrease means that Scotland could be on track to eliminate coronavirus by the end of the summer. Speaking to the BBC, she said, "We are going to see little bumps, so it's a question of how small we can keep those bumps."

She said that the biggest challenge will be managing the importation of new cases, particularly from people travelling from England where hundreds of cases are still being reported daily.

Ian Boyd, professor of biology at St Andrews University, who is a member of the UK government's scientific advisory group, cautioned against claiming victory over covid-19. While he said Scotland is doing comparatively well it would be wrong to be "excessively optimistic about how much control we have over this disease."

He said, “We don't fully understand the dynamics of it, and we don't fully understand why Scotland is doing better than other parts of the country. We shouldn't delude ourselves into thinking that because we've been effective, we know about this disease."

Scotland's three month lockdown is set to be relaxed significantly over the coming weeks which has left Sturgeon feeling anxious about what could happen. "The virus has not gone away, and it will not go away of its own accord. A big concern for me is that, as we ease more restrictions, people drop their guard," she said

1 National Records of Scotland. Deaths involving coronavirus in Scotland. www.nrscotland.gov.uk/covid19stats.

This article is made freely available for use in accordance with BMJ's website terms and conditions for the duration of the covid-19 pandemic or until otherwise determined by BMJ. You may use, download and print the article for any lawful, non-commercial purpose (including text and data mining) provided that all copyright notices and trade marks are retained. 